\title{
EFFECT OF DELIVERY AND EPISIOTOMY ON THE EMERGENCE OF URINARY INCONTINENCE IN WOMEN: REVIEW OF LITERATURE
}

\author{
Krešimir Živković ${ }^{1}$, Nikica Živković ${ }^{2}$, Tomislav $\check{Z ̆ u p i c ́}^{3}$, Damir Hodžić ${ }^{4}$, \\ Vjekoslav Mandić ${ }^{5}$ and Slavko Orešković ${ }^{3}$
}

\begin{abstract}
${ }^{1}$ University of Zagreb, School of Medicine, Clinical Department of Gynecology and Obstetrics, Sveti Duh University Hospital, Zagreb; ${ }^{2}$ Šibenik General Hospital, Department of Gynecology and Obstetrics,

Šibenik; ${ }^{3}$ University of Zagreb, School of Medicine, Zagreb University Hospital Center, Clinical Department of Gynecology and Obstetrics; ${ }^{4}$ University of Zagreb, Merkur University Hospital, Clinical Department of Gynecology and Obstetrics, Zagreb, Croatia; ${ }^{5}$ Mostar University Hospital, Department of Gynecology and Obstetrics, Mostar, Bosnia and Herzegovina
\end{abstract}

\begin{abstract}
SUMMARY - Episiotomy is obstetric procedure during which the incision extends the vestibule of the vagina during the second stage of labor. Episiotomy was extensively spread with gradual increase of rates in the first half of the $20^{\text {th }}$ century and was performed mediolaterally in all nulliparous women with the idea to protect fetal head from trauma and pelvic floor from injuries. However, reports claiming that episiotomy had no such benefits were published. It was shown that routine mediolateral episiotomy did not protect against the appearance of urinary incontinence after vaginal delivery, while the risk of anal incontinence could be increased. The role of episiotomy in development of pelvic floor dysfunction remains quite unclear. Due to the mentioned reason, restricted episiotomy approach should be accepted. The origin of stress incontinence during pregnancy is controversial and not definitely scientifically proven. Pregnancy per se and older age at first delivery may have impact on the onset of pelvic floor dysfunction. Urinary incontinence in pregnancy increases the risk of later urinary incontinence, both postpartum and later in life. Vaginal delivery is just one of the potential risk factors for development of urinary incontinence. Mechanical pressure by fetus on the pelvic floor structures, limited denervation of the pelvic floor and soft tissue damage during delivery are some of explanations for the onset of stress urinary incontinence. On the other hand, cesarean delivery might not be protective against emergence of urinary incontinence. Further research in this field is needed.
\end{abstract}

Key words: Urinary incontinence; Pelvic floor disorders; Pregnancy; Episiotomy; Childbirth

\section{Introduction}

Episiotomy is obstetric procedure during which the surgical incision extends the vestibule of the vagina during the second stage of labor. Episiotomy was first described in $1741^{1}$ and first recommended in 1920 to

Correspondence to: Krešimir Živković, MD, University of Zagreb, School of Medicine, Clinical Department of Gynecology and Obstetrics, Sveti Duh University Hospital, Sveti Duh 64, HR-10000 Zagreb, Croatia

E-mail: kresimirzivkovic@yahoo.com

Received July 14, 2016, accepted September 28, 2016 be performed mediolaterally in all nulliparous women to protect fetal head from trauma and pelvic floor from extreme lacerations ${ }^{2}$. Episiotomy was extensively spread in the world with gradual increase of rates in the first half of the $20^{\text {th }}$ century. However, reports claiming that episiotomy had no such benefits were published ${ }^{3}$ and large studies stressed that routine implementation of episiotomy should be abandoned ${ }^{4,5}$. Pregnancy by itself and childbirth are the possible risk factors for the onset of urinary incontinence, anal incontinence and pelvic organ prolapse, compromising the quality of life for a large number of women of all ages ${ }^{6}$. 
Stress urinary incontinence is a significant health problem which restricts daily activity of women, although many women consider it as a minor health problem and a natural consequence of childbirth ${ }^{7,8}$.Although symptoms could be heavy, small proportions of women seek professional help ${ }^{9,10}$. The etiology of urinary incontinence is multifactorial, but obesity and aging, as well as obstetric trauma are known to be the most important risk factors ${ }^{11,12}$. Urinary incontinence is defined as the involuntary loss of urine and is evidently a social and hygienic problem. It can be classified in three main types: stress, urge, and mixed urinary incontinence. Stress urinary incontinence is leakage of urine during physical activity, coughing and all activities which increase intra-abdominal pressure. It is most commonly caused by a loss of anatomical support of the urethro-vesical junction, i.e. urethral hypermobility, deficiency of the urethral sphincter, or both. Urge incontinence is leakage of urine accompanied with strong desire to void, and is caused by hyperactivity of smooth muscles of the bladder wall ${ }^{13}$. Stress urinary incontinence affects $86 \%$ of incontinent women, either alone $(50 \%)$ or in combination with urge incontinence $(36 \%)^{14}$. DeLancey et al. suggest that the cause of stress incontinence is attributable to the increase of urethral mobility and abnormal urethral sphincter function with low urethral closure pressure ${ }^{15}$. Lower maximal urethral closure pressure is the parameter most associated with de novo stress incontinence after first vaginal childbirth followed by vesical neck mobility ${ }^{15}$. A series of risk factors seem to be involved in urinary incontinence postpartum and later in life, among which there is growing evidence for the impact of delivery mode ${ }^{6,8,16-18}$. Pregnancy per se may have impact on the development of pelvic floor dysfunction. Hormonal changes during pregnancy and the mechanical pressure effects with the peak in the third trimester and at term are the factors that affect the pelvic floor structures ${ }^{18}$. First pregnancy and delivery are believed to carry a particularly high risk of developing stress incontinence ${ }^{19,20}$, although the symptoms may resolve during puerperium ${ }^{19}$.

\section{Impact of Pregnancy and Delivery on Urinary Incontinence}

The origin of stress incontinence during pregnancy is controversial and still not definitely scientifically proven. Hormonal changes or elevated elastic tissue deterioration may soften the collagenous fibers that support the urethra and bladder neck ${ }^{19,21}$. Degenerative changes in the autonomic nervous system of the lower urinary tract or mechanical pressure effect of the gravid uterus may be contributing factors ${ }^{22}$ (Fig. 1). Although the prevalence of stress incontinence is higher during pregnancy than after delivery, it is generally believed that delivery carries a higher risk of initiating long-term symptoms than pregnancy itself ${ }^{19,20}$. In one longitudinal cohort study, the risk of stress incontinence 5 years after the first delivery was, however, not significantly different in women with the onset of symptoms during pregnancy as compared to women with the onset of symptoms during puerperium ${ }^{23}$. Women with the onset of stress urinary incontinence during pregnancy could be predisposed to damage at delivery. This may explain why episiotomy at first delivery in women with the onset of symptoms during first pregnancy leads to a significant increase in longlasting stress incontinence ${ }^{23}$. The true impact of pregnancy on long-lasting stress incontinence is quite unclear.

The effect of vaginal delivery is just one of the potential risk factors for development of urinary incontinence after delivery and later in woman's life. Limited denervation of the pelvic floor is supposed to be pudendal nerve injury resulting from vaginal delivery injuries or prolonged abdominal pulling during fetal expulsion ${ }^{24}$. Soft tissue damage during childbirth might weaken post-delivery bladder neck support and as a consequence can produce some sort of weakness of paraurethral connective tissue and fascial structures, altogether resulting in stress urinary incontinence ${ }^{25-27}$. Fibrosis and damages to the levator ani muscle during vaginal childbirth may also contribute to this condition ${ }^{28}$.

Some findings suggest that first pregnancy and delivery in particular predispose development of stress incontinence, which is in accordance with a study in a large group of young multiparous women ${ }^{20}$. There are reports supporting a theory that pelvic floor innervation is likely to be injured predominantly after the first delivery and subsequent deliveries could possibly aggravate the already existing injury ${ }^{29}$. A large epidemiological study implies that increasing parity can increase the risk of the onset of stress incontinence ${ }^{30}$. Some authors state that the influence of subsequent deliveries in developing stress urinary incontinence is exagger- 

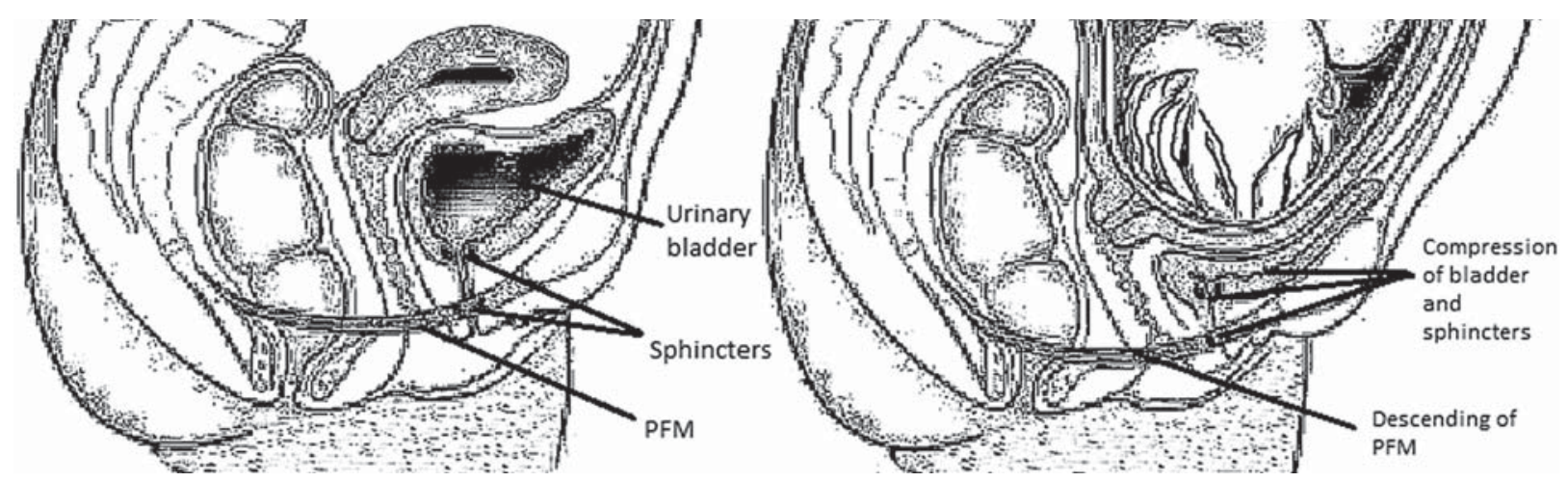

Fig. 1. Compression effects of the gravid uterus on the pelvic floor muscles (PFM) and lower urinary structures in sagittal view.

ated $^{23}$. Apart from parity and age, other risk factors should be considered such as obesity, chronic lung disease and smoking, which all could contribute to the symptoms of urinary incontinence ${ }^{31}$. Pelvic floor disorders are a highly common condition in the immediate postpartum period, with a prevalence of $18.4 \%$ in primiparous women and $24.6 \%$ in secundiparae ${ }^{32}$. It has been estimated that the prevalence of urinary incontinence three months postpartum is around 30\% of women with previously spontaneous vaginal delivery, while for women having delivered by cesarean section the rate is $15 \% \%^{17,33,34}$. A study in 4200 women conducted six years after delivery showed that those that had only vaginal delivery and those that had delivered both vaginally and by cesarean section had an approximately equal prevalence of urinary leakage $(26 \%$ and $28 \%$, respectively). However, the prevalence among those having delivered only by cesarean section was $14 \%{ }^{35}$. A large retrospective population-based observational study $^{12}$ in a population of 15,300 women found the prevalence of urinary leakage of $10 \%$ in the nulliparous group and $16 \%$ in the cesarean section group, while in the group that had only vaginal deliveries the rate was $24 \%$. Furthermore, this study found that women aged over 50 had no protective effect from cesarean section anymore $^{12}$. Other factors that may have unfavorable influence are older age at first childbirth and primiparity $^{36,37}$. In the previously mentioned study by Rortveit et al., the incidence of stress urinary incontinence was $4.7 \%, 6.9 \%$ and $12.2 \%$ in the nulliparous, cesarean section and vaginal delivery groups, respectively. The respective rates of urge urinary incontinence were $1.6 \%$, $2.2 \%$ and $1.8 \%$, and of mixed urinary incontinence $3.1 \%, 5.3 \%$ and $6.1 \%$. Adjusted odds ratio for any type of urinary incontinence was found to be 1.5 in the cesarean group as compared with nulliparous women (95\% CI 1.2-1.9). In case of vaginal delivery in comparison with cesarean delivery, the odds ratio for any type of urinary incontinence was found to be 1.7 (95\% CI 1.3-2.1) and that for severe incontinence 2.2 (95\% CI 1.7-3.2). The risk of stress urinary incontinence increased 2.5-fold in case of vaginal delivery as compared to cesarean delivery. This research implies that cesarean delivery might not protect against urinary incontinence $^{12}$. It appears that a woman must have all children delivered by cesarean section in order to achieve protection against long-term incontinence ${ }^{35}$. Urinary incontinence in pregnancy increases the risk of later urinary incontinence, both postpartum and later in life ${ }^{17,38}$, but nevertheless it is not a predictor of benefit from giving birth by cesarean section to protect against urine leakage ${ }^{17,39}$. Increase of urethral mobility in combination with lesions of the levator ani muscle is the probable mechanism of impairment during vaginal delivery ${ }^{40}$. Nevertheless, urethral hypermobility returns to pre-delivery rates after few months postpartum $^{41}$. Some authors found no connection between urethral mobility and postpartum urinary incontinence $^{42}$. According to DeLancey et al., only $16 \%$ of postpartum stress urinary incontinence could be explained by urethral mobility, whereas urethral closure pressure could account for $25 \%$ of post-delivery stress urinary incontinence ${ }^{15}$. The link between muscle levator ani avulsion and postpartum stress urinary incontinence was not confirmed ${ }^{43}$. The connection between urethral closure pressure and gravidity still remains quite unclear. Fritel et al. found that the association between maternal age and urinary incontinence could 
be explained by a lower urethral closure pressure, as the latter is known to decrease with advancing maternal age $^{44}$. The underlying mechanisms of post-delivery urinary incontinence and anal incontinence have been shown to be different, implying that different strategies may be needed for their prevention ${ }^{43}$. Women that practice regular pelvic floor exercises from midterm pregnancy have a reduced risk of the onset of urinary incontinence, as well as anal incontinence, supporting the importance of pelvic floor exercises during pregnancy to prevent pelvic floor dysfunction ${ }^{45}$. The reported pregnancy and delivery related risk factors for the emergence of urinary incontinence are pre-pregnancy body mass index (BMI), BMI at term, weight gain, smoking during pregnancy, duration of the first and second stages of labor, spontaneous or operative delivery, perineal lacerations, weight of the newborn, maneuvers and episiotomy, as well as epidural analgesia ${ }^{32}$. Having all this in mind, the mechanisms of initial injury are still largely unknown. The impact of delivery on the occurrence of stress urinary incontinence is just one of the factors, making urinary incontinence a quite multifactorial disorder.

The association between the mode of delivery and overactive bladder syndrome has not yet been well established. The probability for the onset of overactive bladder syndrome does not differ significantly between women having delivered vaginally and by cesarean section $^{46}$. Palma et al. state that pregnancy per se rather than the mode of delivery is a risk factor for development of overactive bladder ${ }^{47}$. Overactive bladder symptoms were more likely to be seen among multiparous women as compared to primiparous women. Symptoms of overactive bladder are more frequently seen in women having delivered vaginally than in the group of women having delivered by cesarean section, but the difference did not reach statistical significance $^{47}$. Vacuum and forceps assisted delivery increases the risk of overactive bladder development ${ }^{48}$.

\section{Types of Episiotomy}

Most obstetric textbooks describe only two types of episiotomy, mediolateral and median ${ }^{49}$, although there are more (Fig. 2). The main types of episiotomy are medial, modified medial, mediolateral, lateral, "J" and Schuchardt incision ${ }^{50}$. Median episiotomy cut begins from the posterior fourchette vertically to the

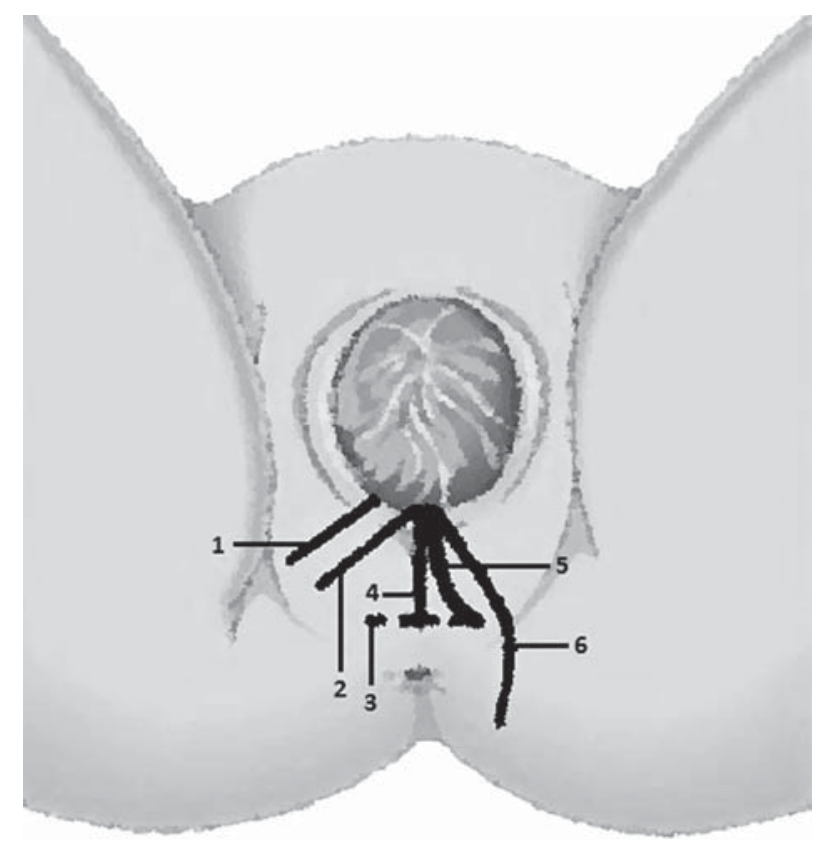

Fig. 2. Types of episiotomy: 1 - lateral; 2 - mediolateral; 3 - modified median episiotomy; 4- median episiotomy; 5 - "J" shaped episiotomy; and 6 - Schuchardt incision.

perineum, and it scratches to half the thickness of the perineum. Modified median episiotomy has the same direction as the medial one and is performed by adding two transverse incisions in opposite directions just above the expected location of the anal sphincter. Lateral episiotomy cut starts $1-2 \mathrm{~cm}$ of the posterior fourchette in the direction of ischial tuberosity, whereas mediolateral episiotomy is directed from midline (posterior fourchette) or $3 \mathrm{~mm}$ of it at the angle of at least 60 degrees to ischial tuberosity. Schuchardt incision starts from the same place as lateral episiotomy, but with a slightly smaller angle and in a gentle curve passes laterally to the rectum to ischiorectal fossa. It is very rare in the current obstetric practice, performed only with very difficult fetal expulsion. J-incision commences with a midline incision and is then curved laterally to avoid the anus in the direction of ischial tuberosity and looks like letter "J". There are currently no international guidelines for episiotomy to be incised on the right or the left side and some maternity wards in Europe classify lateral episiotomy as mediolateral ${ }^{51}$. Lateral type is used in Finland ${ }^{52,53}$, whereas Greeks use lateral episiotomy, but wrongly classify it as mediolateral ${ }^{54}$. Very large differences in classification and terminology have recently been resolved to a certain de- 
gree $^{50}$. In the light of the facts mentioned above, lateral episiotomy is rarely mentioned in the obstetric literature, despite its wide usage. The larger angle of episiotomy has been proven to carry a lower risk of anal sphincter and pelvic floor injuries ${ }^{55-57}$. Large observational studies have shown that with increasing the angle of lateral episiotomy, the incision has a protective effect on the onset of anal sphincter inju$\mathrm{ry}^{53,55,58-60}$. Studies dealing with the effect of lateral episiotomy on urinary and anal incontinence and medium-longterm sexual function are not found by searching literature databases. It has been shown that medial and mediolateral episiotomies do not protect pelvic floor from relaxation and dysfunction, with no favorable effect on the occurrence of stress urinary incontinence and anal incontinence ${ }^{61}$.

\section{Impact of Episiotomy on Urinary Incontinence after Delivery}

There are two approaches in the use of episiotomy in obstetrics today, restrictive and routine approach. The restricted approach is used with increasing frequency and represents the use of episiotomy according to obstetric indication. In a meta-analysis that included all major randomized clinical trials, Carroli and Mignini ${ }^{62}$ found that restrictive episiotomy compared to routine use of episiotomy resulted in less perineal lacerations and ruptures with fewer postoperative complications. There was no difference in postpartum perineal pain, incidence and severity of trauma, and urinary incontinence after childbirth. Leading experts in this field recommend the use of restricted approach, i.e. in accordance with obstetric indications (operative vaginal delivery, fetal hypoxia, and inelastic rigid perineum $)^{5}$. Klein et al. found no difference in perineal trauma and pain after vaginal delivery with the use of restrictive midline episiotomy in primiparous women compared to routine approach. There was no difference in urinary incontinence and other symptoms of pelvic floor damage 3 months following delivery either, suggesting that routine episiotomy has not protective effect on the pelvic floor ${ }^{63}$. One study dealing with the phenomenon of pelvic relaxation after vaginal delivery showed that episiotomy caused decreased strength of pelvic floor muscles ${ }^{64}$. Similar results have been reported by Sartore et al..$^{65}$, stating that mediolateral episiotomy does not protect against the appearance of stress urinary incontinence, anal incontinence and female genital prolapse. According to Pregazzi et al. ${ }^{66}$, detailed classification of perineal ruptures immediately after delivery is not proven to be a good predictor of the occurrence of pelvic relaxation and stress urinary incontinence. The risk of developing urinary incontinence was found to be by $67 \%-71 \%$ higher after vaginal delivery as compared to cesarean section in a population-based cohort of singleton primiparae ${ }^{67}$. Fritel et al. state that routine mediolateral episiotomy in a population of primiparae does not protect against the appearance of urinary incontinence in 4-year period after vaginal delivery, while the risk of anal incontinence is increased ${ }^{68}$. Moreover, according to several major observational and cohort studies, episiotomy could be a risk factor for the onset of pelvic floor disorders ${ }^{23,69,70}$. Few authors state that episiotomy does not affect the incidence of pelvic floor disorders ${ }^{48}$. As already mentioned, vaginal delivery carries a higher risk of urinary incontinence but anal sphincter injuries do not affect the occurrence of urinary incontinence. Some authors report a similar incidence of urinary incontinence after vaginal delivery and cesarean section ${ }^{71}$. Intrapartum cesarean section lost protective effect on the occurrence of urinary incontinence and only per-delivery elective cesarean section retains protective effect ${ }^{71}$. According to Casey et al., episiotomy increases the risk of urinary incontinence alone as an independent factor, and in association with other factors (macrosomia, epidural analgesia, and oxytocin augmentation of delivery $)^{69}$. The same study suggests a protective effect of cesarean section on the occurrence of stress and urge urinary incontinence ${ }^{69}$.

Restricted use of episiotomy increases the rate of perineal lacerations that are not associated with the occurrence of stress urinary incontinence ${ }^{72}$. Some researchers state that the phenomenon of stress urinary incontinence during pregnancy doubles the chance for the emergence of urinary incontinence after delivery ${ }^{6}$. Fetal weight, episiotomy, length of the second stage of labor and epidural analgesia were not predictive factors for stress urinary incontinence ${ }^{6}$. In addition, the prospective study by Chang et al. comparing a group of vaginal delivery without episiotomy and a group with vaginal delivery with episiotomy showed the incidence of urinary incontinence to be significantly higher in the group with episiotomy ${ }^{73}$. 


\section{Discussion}

Bozkurt et al. ${ }^{18}$ have clearly summarized results from the existing literature and presented the main points of the researches in this field, as follows: 1) a total of $65 \%$ of patients with incontinence remember that the first episode of incontinence happened during pregnancy or in the postpartum period; 2) having a history of the first vaginal delivery at the older age may be one of the major risk factors for pelvic floor damage; 3) routine episiotomy should no longer be used in modern obstetric practice, as it cannot prevent direct trauma to the pelvic floor muscles; 4) pregnancy itself is the most important and independent risk factor for pelvic floor dysfunction, so pelvic floor muscle exercises performed during pregnancy and in early postpartum period may be protective against urinary incontinence during late trimesters of pregnancy and late postpartum period, as well as against anal incontinence; 5) elective cesarean delivery (before the onset of labor) seems to lower the risk of postpartum urinary incontinence within a short period of time. However, cesarean delivery does not prevent urinary incontinence and anal incontinence at long term; and 6) not enough scientific data are available to recommend elective cesarean delivery in order to prevent pelvic floor dysfunction.

We can say that the majority of studies investigating the impact of episiotomy on urine continence involved mediolateral and medial episiotomy. Most of the results suggest that episiotomy has an adverse effect on the pelvic floor after childbirth, although the results are partially incoherent. It is important to stress that most of the studies were limited in terms of levels of evidence. Despite all studies, there are not enough evidence-based data confirming that vaginal delivery and episiotomy are the only factors responsible for pelvic floor disorders and onset of urinary incontinence. Therefore, the role of episiotomy as a risk factor or protective factor for the development of pelvic floor dysfunction remains unknown, which was confirmed in a large systematic review by Hartmann et al. ${ }^{5}$. Pregnancy itself may be one of the most important risk factors for the development of pelvic floor dysfunction. It is difficult to compare cesarean delivery with vaginal delivery in terms of pelvic floor dysfunction, or delivery with restrictive episiotomy versus delivery with spontaneous lacerations due to different study designs, fol- low up periods and measuring tools. Well-organized and planned, prospective, double-blind, randomized multicenter studies are needed in this field of research. Randomized controlled trials should include patients with homogenized risk factors and other types of studies that must include a maximally homogeneous sample. Only in such a manner, we will be able to make clear and definitive conclusion on the impact of the delivery mode and role of episiotomy on stress urinary incontinence. Many theories made the relation between pregnancy and delivery relative to the emergence of stress urinary incontinence more complex to understand clearly. In addition, the interval between the first pregnancy and the onset of urinary incontinence symptoms is quite elongated; the mean age at surgery for stress urinary incontinence is the fifties, about 30 years after first childbirth ${ }^{74}$. This is the reason why it is difficult to establish a strong link between obstetric events and urine incontinence demanding surgical treatment in later years. Studies dealing with long-term outcome involving women at the end of reproductive age are required. It is possible that pregnancy per se could be a great risk factor for severe stress urinary incontinence in some women in their fifties. Additionally, there is no confirmed causal link between urinary problems in the early post-delivery period and those with the onset of symptoms around the menopause. Long-term impact of the mode of delivery (spontaneous, operative vaginal or cesarean) on severe stress urinary incontinence seems to be insignificant.

\section{Conclusion}

In conclusion, according to the available literature it appears that episiotomy does not protect against the appearance of stress urinary incontinence; moreover, some designate it as a risk factor. According to the majority of high-quality studies, the phenomenon of stress urinary incontinence is not causally associated with episiotomy. Probably muscle strength is decreased in women with episiotomy, thus making possible the development of the phenomenon of pelvic relaxation in this group. The impact of pregnancy per se on the onset of stress urinary incontinence is greatly underestimated. Restrictive approach is recommended in daily routine considering the non-protective effect of episiotomy on the pelvic floor. The role of cesarean section 
as a method of avoiding urinary incontinence is greatly questionable.

\section{References}

1. Ould F. A treatise on midwifery in three parts. Dublin, Ireland: Oli, Nelson and Charles Connor; 1742.

2. DeLee JB. The prophylactic forceps operation. Am J Obstet Gynecol. 1920;1:34-44.

3. Thacker SB, Banta HD. Benefits and risks of episiotomy: an interpretative review of the English language literature, 18601980. Obstet Gynecol Surv. 1983;38:322-38.

4. Argentine Episiotomy Trial Collaborative Group. Routine vs selective episiotomy: a randomized controlled trial. Lancet. 1993; 342:1517-8. doi: 10.1016/S0140-6736(05)80085-6

5. Hartmann K, Viswanathan M, Palmieri R, Gartlehner G, Thorp J Jr, Lohr KN. Outcomes of routine episiotomy: a systematic review. JAMA. 2005;293(17):2141-8. doi:10.1001/ jama.293.17.2141

6. Eason E, Labrecque M, Marcoux S, Mondor M. Effects of carrying a pregnancy and of method of delivery on urinary incontinence: a prospective cohort study. BMC Pregnancy Childbirth. 2004;4(1):4. doi: 10.1186/1471-2393-4-4

7. Chaliha C, Kalia V, Stanton SL, Monga A, Sultan AH. Antenatal prediction of postpartum urinary and fecal incontinence. Obstet Gynecol. 1999;94:689-94. doi: 10.1016/s0029-7844 (99)00364-6

8. Mason L, Glenn S, Walton I, Appleton C. The experience of stress incontinence after childbirth. Birth. 1999;26:164-71. doi: 10.1046/j.1523-536x.1999.00164.x

9. Mason L, Glenn S, Walton I, Hughes C. Women's reluctance to seek help for stress incontinence during pregnancy and following childbirth. Midwifery. 2001;17:212-21. doi: 10.1054/ midw.2001.0259

10. Chiarelli P, Brown WJ. Leaking urine in Australian women: prevalence and associated conditions. Women Health. 1999; 29:1-13.

11. Milsom I, Altman D, Herbison P, Lapitan MC, Nelson R, Sille' n U, et al. Epidemiology of urinary (UI) and faecal (FI) incontinence and pelvic organ prolapse (POP). In: Abrams Paul, Cardozo Linda, Khoury Saad, Wein Alan, editors. Incontinence. Paris: Health Publications Ltd.; 2009. pp. 35-111.

12. Rortveit G, Daltveit AK, Hannestad YS, Hunskaar S. Urinary incontinence after vaginal delivery or cesarean section. N Engl J Med. 2003;348:900-7. doi: 10.1056/NEJMoa021788

13. Culligan PJ, Heit M. Urinary incontinence in women: evaluation and management. Am Fam Physician. 2000;62(11): 2433-44, 2447, 2452.

14. Hannestad YS, Rortveit G, Sandvik H, Hunskaar S, Norwegian EPINCONT study. Epidemiology of Incontinence in the County of Nord-Trøndelag. J Clin Epidemiol. 2000;53(11): 1150-7.
15. DeLancey JO, Miller JM, Kearney R, Howard D, Reddy P, Umek W, et al. Vaginal birth and de novo stress incontinence: relative contributions of urethral dysfunction and mobility. Obstet Gynecol. 2007;110:354-62. doi: 10.1097/01.AOG. 0000270120.60522 .55

16. Burgio KL, Zyczynski H, Locher JL, Richter HE, Redden DT, Wright KC. Urinary incontinence in the 12-month postpartum period. Obstet Gynecol. 2003;102:1291-8. doi: 10.1016/j. obstetgynecol.2003.09.013

17. Wesnes SL, Hunskaar S, Bo K, Rortveit G. The effect of urinary incontinence status during pregnancy and delivery mode on incontinence postpartum. A cohort study. BJOG. 2009;116:700-7. doi: 10.1111/j.1471-0528.2008.02107.x

18. Bozkurt M, Yumru AE, Şahin L. Pelvic floor dysfunction, and effects of pregnancy and mode of delivery on pelvic floor. Taiwan J Obstet Gynecol. 2014;53(4):452-8. doi: http://dx.doi. org/10.1016/j.tjog.2014.08.001

19. Viktrup L, Lose G, Rolff M, Barfoed K. The symptom of stress incontinence caused by pregnancy or delivery in primiparas. Obstet Gynecol. 1992;79:945-9.

20. Højberg K, Salvig JD, Winsløw NA, Lose G, Secher NJ. Urinary incontinence: prevalence and risk factors at 16 weeks of gestation. BJOG. 1999;106:842-50. doi: 10.1111/j.1471-0528. 1999.tb08407.x

21. Mathrubutham M, Aybek Z, Fogarty J, Lee J, Rao SK, Badlani $\mathrm{GH}$, et al. Plasma elastase regulation in stress urinary incontinence. Neurourol Urodyn. 1999;18:281-2.

22. Grandadam F, Lluel P, Palea S, Martin DJ. Pharmacological and urodynamic changes in rat urinary bladder function after multiple pregnancies. BJU Int. 1999;84:861-6. doi: 10.1046/ j.1464-410x.1999.00282.x

23. Viktrup L, Lose G. The risk of stress incontinence 5 years after first delivery. Am J Obstet Gynecol. 2001;185:82-7. doi: 10.1067/mob.2001.114501

24. Smith ARB, Hosker GL, Warrell DW. The role of pudendal nerve damage in the aetiology of genuine stress incontinence of urine in women. BJOG. 1989;96:29-32. doi: 10.1111/j.1471-0528.1989.tb01572.x

25. Peschers U, Schaer G, Anthuber C, Delancey JOL, Schuessler B. Changes in vesical neck mobility following vaginal delivery. Obstet Gynecol. 1996;88:1001-6. doi: 10.1016/S0029-7844 (96)00338-9

26. Falconer C, Blomgren B, Johansson O,Ulmsten U, Malmstrøm A, Westergren-Thorsson G, et al. Different organization of collagen fibrils in stress-incontinent women of fertile age. Acta Obstet Gynecol Scand. 1998;77:87-94.

27. Norton PA. Pelvic floor disorders: the role of fascia and ligaments. Clin Obstet Gynecol. 1993;36:926-38.

28. Dimpf T, Jaeger C, Muelller-Felber W, Anthuber C, Hirsch A, Brandmaier R, et al. Myogenic changes of the levator ani muscle in premenopausal women: the impact of vaginal delivery and age. Neurourol Urodyn. 1998;17:197-205. 
29. Snooks SJ, Swash M, Henry MM, Setchell M. Risk factors in childbirth causing damage to the pelvic floor innervation. Br J Surg. 1985;72 Suppl:15-7. doi: 10.1002/bjs.1800721311

30. Jolleys JV. Reported prevalence of urinary incontinence in women in a general practice. BMJ. 1988;296:1300-2.

31. Bump RC. Discussion: Epidemiology of urinary incontinence. J Urol. 1997;50 Suppl:15-7.

32. Bertozzi S, Londero AP, Fruscalzo A, Driul L, Delneri C, Calcagno A, et al. Impact of episiotomy on pelvic floor disorders and their influence on women's wellness after the sixth month postpartum: a retrospective study. BMC Women Health. 2011;11:12. doi: 10.1186/1472-6874-11-12

33. Thom DH, Rortveit G. Prevalence of postpartum urinary incontinence: a systematic review. Acta Obstet Gynecol Scand. 2010;89:1511-22. doi: 10.3109/00016349.2010.526188

34. Boyles SH, Li H, Mori T, Osterweil P, Guise JM. Effect of mode of delivery on the incidence of urinary incontinence in primiparous women. Obstet Gynecol. 2009;113:134-41. doi: 10.1097/AOG.0b013e318191bb37

35. MacArthur C, Glazener CM, Wilson PD, Lancashire RJ, Herbison GP, Grant AM. Persistent urinary incontinence and delivery mode history: a six-year longitudinal study. BJOG. 2006;113(2):218-24. doi: 10.1111/j.1471-0528.2005.00818.x

36. Groutz A, Helpman L, Gold R, Pauzner D, Lessing JB, Gordon $\mathrm{D}$. First vaginal delivery at an older age: does it carry an extra risk for the development of stress urinary incontinence? Neurourol Urodyn. 2007;26:779-82. doi: 10.1002/nau.20414

37. Rortveit G,Hannestad YS, Daltveit AK, Hunskaar S. Age- and type-dependent effects of parity on urinary incontinence: the Norwegian EPINCONT study. Obstet Gynecol. 2001;98: 1004-10. doi: 10.1016/S0029-7844(01)01566-6

38. Viktrup L, Rortveit G, Lose G. Risk of stress urinary incontinence twelve years after the first pregnancy and delivery. Obstet Gynecol. 2006;108:248-54. doi: 10.1097/01.AOG. 0000226860.01127

39. Arrue M, Diez-Itza I, Ibañez L, Paredes J, Murgiondo A, Sarasqueta C. Factors involved in the persistence of stress urinary incontinence from pregnancy to 2 years post partum. Int J Gynaecol Obstet. 2011;115:256-9. doi: 10.1016/j.ijgo.2011. 07.024

40. DeLancey JO, Kearney R, Chou Q, Speights S, Binno S. The appearance of levator ani muscle abnormalities in magnetic resonance images after vaginal delivery. Obstet Gynecol. 2003; 101:46-53. doi: 10.1016/S0029-7844(02)02465-1

41. Toozs-Hobson P, Balmforth J, Cardozo L, Khullar V, Athanasiou $\mathrm{S}$. The effect of mode of delivery on pelvic floor functional anatomy. Int Urogynecol J Pelvic Floor Dysfunct. 2008;19:407-16. doi: 10.1007/s00192-007-0455-0

42. Wijma J, Potters AE, de Wolf BT, Tinga DJ, Aarnoudse JG. Anatomical and functional changes in the lower urinary tract following spontaneous vaginal delivery. BJOG. 2003;110: 658-63. doi: 10.1046/j.1471-0528.2003.02296.x

43. Dietz HP, Lanzarone V. Levator trauma after vaginal delivery. Obstet Gynecol. 2005;106:707-12. doi: 10.1097/01.AOG. 0000178779.62181 .01
44. Fritel X, Khoshnood B, Fauconnier A. Specific obstetrical risk factors for urinary versus anal incontinence 4 years after first delivery. Prog Urol. 2013(11):911-6. doi: 10.1016/j.purol. 2013.06.009

45. Hilde G, Stær-Jensen J, Ellström Engh M, Brækken IH, Bø K. Continence and pelvic floor status in nulliparous women at midterm pregnancy. Int Urogynecol J. 2012;23(9):1257-63. doi: 10.1007/s00192-012-1716-0

46. Handa VL, Blomquist JL, Knoepp LR, Hoskey KA, McDermott KC, Munoz A. Pelvic floor disorders 5-10 years after vaginal or cesarean childbirth. Obstet Gynecol. 2011;118: 777-84. doi: 10.1097/AOG.0b013e3182267f2f

47. Palma T, Raimondi M, Souto S, Fozzatti C, Palma P, Riccetto C. Prospective study of prevalence of overactive bladder symptoms and child-bearing in women of reproductive age. J Obstet Gynaecol Res. 2013;39:1324-9. doi: 10.1111/jog.12063

48. Handa VL, Blomquist JL, McDermott KC, Friedman S, Muñoz A. Pelvic floor disorders after vaginal birth: effect of episiotomy, perineal laceration, and operative birth. Obstet Gynecol. 2012;119:233-9. doi: 10.1097/AOG.0b013e318240df4f

49. Arulkumaran S. Malpresentation, malposition, cephalopelvic dysproportion and obstetric procedures. In: Edmonds DK, editor. Dewhurst's Textbook of Obstetrics and Gynaecology, $7^{\text {th }}$ edn. Oxford: Blackwell Publishing, 2007. pp. 213-26.

50. Kalis V, Laine K, de Leeuw JW, Ismail KM, Tincello DG. Classification of episiotomy: towards a standardisation of terminology. BJOG. 2012;(5):522-6. doi: 10.1111/j.1471-0528. 2011.03268. $\mathrm{x}$

51. Kalis V, Stepan J Jr, Horak M, Roztocil A, Kralickova M, Rokyta Z. Definitions of mediolateral episiotomy in Europe. Int J Gynecol Obstet. 2008;100:188-9. doi: 10.1016/j.ijgo. 2007.07.022

52. Laine K, Gissler M, Pirhonen J. Changing incidence of anal sphincter tears in four Nordic countries through the last decades. Eur J Obstet Gynecol Reprod Biol. 2009;146:71-5. doi: 10.1016/j.ejogrb.2009.04.033

53. Räisänen SH, Vehviläinen-Julkunen K, Gissler M, Heinonen $\mathrm{S}$. Lateral episiotomy protects primiparous but not multiparous women from obstetric anal sphincter rupture. Acta Obstet Gynecol Scand. 2009;88(12):1365-72. doi: 10.3109/0001634 0903295626

54. Grigoriadis T, Athanasiou S, Zisou A, Antsaklis A. Episiotomy and perineal repair practices among obstetricians in Greece. Int J Gynaecol Obstet. 2009;106:27-9. doi: 10.1016/j.ijgo. 2009.03.013

55. Stedenfeldt M, Pirhonen J, Blix E, Wilsgaard T, Vonen B, Øian P. Episiotomy characteristics and risks for obstetric anal sphincter injuries: a case-control study. BJOG. 2012;119(6): 724-30. doi: 10.1111/j.1471-0528.2012.03293.x

56. Kalis V, Landsmanova J, Bednarova B, Karbanova J, Laine K, Rokyta Z. Evaluation of the incision angle of mediolateral episiotomy at 60 degrees. Int J Gynaecol Obstet. 2011;112:220-4. doi: 10.1016/j.ijgo.2010.09.015 
57. Eogan M, Daly L, O'Connell PR, O'Herlihy C. Does the angle of episiotomy affect the incidence of anal sphincter injury? BJOG.2006;113:190-4. doi:10.1111/j.1471-0528.2005.00835.x

58. Räisänen S, Vehviläinen-Julkunen K, Gissler M, Heinonen S. Hospital-based lateral episiotomy and obstetric anal sphincter injury rates: a retrospective population-based register study. Am J Obstet Gynecol. 2012;206(4):347.e1-6. doi: 10.1016/j. ajog.2012.02.019

59. Fodstad K, Laine K, Staff AC. Different episiotomy techniques, postpartum perineal pain, and blood loss: an observational study. Int Urogynecol J. 2013;24(5):865-72. doi: 10.1007/ s00192-012-1960-3

60. Fodstad K, Staff AC, Laine K. Effect of different episiotomy techniques on perineal pain and sexual activity 3 months after delivery. Int Urogynecol J. 2014;25(12):1629-37. doi: 10.1007/ s00192-014-2401-2

61. Woolley RJ. Benefits and risks of episiotomy: a review of the English-language literature since 1983. Parts I and II. Obstet Gynecol Surv. 1995;50:806-35.

62. Carroli G, Mignini L. Episiotomy for vaginal birth. Cochrane Database Syst Rev. 2009;(1):CD000081. doi: 10.1002/ 14651858.CD000081.pub2

63. Klein MC, Gauthier RJ, Jorgensen SH, Robbins JM, Kaczorowski J, Johnson B, et al. Does episiotomy prevent perineal trauma and pelvic floor relaxation? Online J Curr Clin Trials. 1992 Jul 1;Doc No. 10.

64. Röckner G, Jonasson A, Olund A. The effect of mediolateral episiotomy at delivery on pelvic floor muscle strength evaluated with vaginal cones. Acta Obstet Gynecol Scand. 1991;70(1): 51-4. doi: 10.3109/00016349109006178

65. Sartore A, De Seta F, Maso G, Pregazzi R, Grimaldi E, Guaschino $\mathrm{S}$. The effects of mediolateral episiotomy on pelvic floor function after vaginal delivery. Obstet Gynecol. 2004;103 (4):669-73. doi: 10.1097/01.AOG.0000119223.04441.c9

66. Pregazzi R, Sartore A, Bortoli P, Grimaldi E, Ricci G, Guaschino $\mathrm{S}$. Immediate postpartum perineal examination as a pre- dictor of puerperal pelvic floor dysfunction. Obstet Gynecol. 2002;99(4):581-4. doi: 10.1016/S0029-7844(01)01763-X

67. Gyhagen M, Bullarbo M, Nielsen TF, Milsom I. The prevalence of urinary incontinence 20 years after childbirth: a national cohort study in singleton primiparae after vaginal or caesarean delivery. BJOG. 2013;120(2):144-51. doi: 10.1111/ j.1471-0528.2012.03301.x

68. Fritel X, Schaal JP, Fauconnier A, Bertrand V, Levet C, Pigné A. Pelvic floor disorders 4 years after first delivery: a comparative study of restrictive versus systematic episiotomy. BJOG. 2008;115(2):247-52. doi: 10.1111/j.1471-0528.2007. 01540.x

69. Casey B, Schaffer J, Bloom S, Heartwell S, McIntire D, Leveno $\mathrm{KJ}$. Obstetric antecedents for postpartum pelvic floor dysfunction. Am J Obstet Gynecol. 2005;192:1655-62. doi: 10.1016/j. ajog.2004.11.031

70. Tegerstedt G, Miedel A, Maehle-Schmidt M, Nyrén O, Hammarström M. Obstetric risk factors for symptomatic prolapse: a population-based approach. Am J Obstet Gynecol. 2006;194: 75-81. doi: 10.1016/j.ajog.2005.06.086

71. Borello-France D, Burgio KL, Richter HE, Zyczynski H, Fitzgerald MP, Whitehead W, et al. Fecal and urinary incontinence in primiparous women. Obstet Gynecol. 2006;108 (4):863-72. doi: 10.1097/01.AOG.0000232504.32589.3b

72. Rockner G. Urinary incontinence after perineal trauma at childbirth. Scand J Caring Sci. 1990;4:169-72. doi: 10.1111/ j.1471-6712.1990.tb00068.x

73. Chang SR, Chen KH, Lin HH, Chao YM, Lai YH. Comparison of the effects of episiotomy and no episiotomy on pain, urinary incontinence, and sexual function 3 months postpartum: a prospective follow-up study. Int J Nurs Stud. 2011;48(4):409-18. doi: 10.1016/j.ijnurstu.2010.07.017

74. Waetjen LE, Subak LL, Shen H, Lin F, Wang TH, Vittinghoff $\mathrm{E}$, et al. Stress urinary incontinence surgery in the United States. Obstet Gynecol. 2003;101:671-6. doi: 10.1016/S00297844(02)03124-1 


\title{
Sažetak
}

\section{UČINAK POROĐAJA I EPIZIOTOMIJE NA NASTANAK INKONTINENCIJE MOKRAĆE U ŽENA: PREGLED LITERATURE}

\author{
K. Živković, N. Živković, T. Župić, D. Hodžić, V. Mandić i S. Orešković
}

Epiziotomija je porodnička operacija u kojoj se incizijom širi predvorje vagine tijekom drugog porođajnog doba. Epiziotomija se intenzivno koristila uz postupno povećanje stope u prvoj polovici 20. stoljeća kao mediolateralni urez međice na svim prvorodiljama s idejom zaštite glave fetusa od traume i zdjeličnog dna od ozljeda. U posljednje vrijeme objavljeni su radovi koji tvrde da epiziotomija nema prije navedene koristi, odnosno da rutinska mediolateralna epiziotomija ne štiti od pojave stresne inkontinencije mokraće nakon vaginalnog porođaja, dok je rizik od pojave analne inkontinencije povećan. Uloga epiziotomije u razvoju disfunkcije zdjeličnog dna ostaje prilično nejasna. Zbog navedenih razloga restriktivni pristup uporabi epiziotomije bi trebao biti prihvaćen. Uzrok stresne inkontinencije tijekom trudnoće je proturječan i nije definitivno znanstveno dokazan. Trudnoća sama po sebi i starija dob pri prvom porođaju mogu imati utjecaj na nastanak disfunkcije zdjeličnog dna. Također pojava inkontinencije mokraće u trudnoći povećava rizik za nastanak inkontinencije mokraće poslije porođaja i u ostatku života. Vaginalni porođaj je samo jedan od potencijalnih čimbenika rizika za razvoj inkontinencije mokraće. Mehanički pritisak fetusa na zdjelično dno, ograničena denervacija zdjeličnih struktura i oštećenja mekih tkiva tijekom porođaja su neka od objašnjenja za pojavu stresne inkontinencije mokraće. Porođaj carskim rezom vjerojatno ne štiti od pojave inkontinencije mokraće. Sve upućuje na to da su daljnja istraživanja u ovom području neophodna.

Ključne riječi: Inkontinencija mokraće; Poreméaji zdjeličnog dna; Trudnoća; Epiziotomija; Porođaj 